\title{
Effect of Dandelion on serum lipids in Male Albino Rats intoxicated with Oxytetracycline
}

\author{
Abdelrehman M. Attia, Omnia G. Refat, Mona S. Halaby, Alaa \\ O. Aboraya and Sara A. A. Mahmoud
}

Department of Nutrition and Food Science, Faculty of Home

Economics, Helwan University, Cairo-Egypt

\begin{abstract}
Dandelion is a common plant widely used in many countries for its nutritional and medicinal benefits. The main target of this study was to investigate its effect in two different concentrations $(2.5 \%$ \& $5 \%$ ) on blood lipids in male albino rats. The experiment was carried out using twenty-eight male albino rats. These rats were put on basal diet for one week before being divided into four main groups (seven rats each). Group 1: Negative control group continued basal diet during the whole experiment. Group 2: Positive control group was fed on basal diet for 28 days, then injected with Oxytetracycline for threeconsecutive days $(120 \mathrm{mg} / \mathrm{kg}$ body weight) and continued on the basal diet till the end of the experiment . Group 3: continued as group 2 and after being injected rats were given Dandelion powder $2.5 \%$ on the basal diet. Group 4: as the same of group 3 except that rats were given $5 \%$ Dandelion powder. The study continued for one week after the injection of Oxytetracycline. At the end of the experimental period rats were fasted overnight and sacrificed; blood samples were collected from the aorta to determine lipids profiles. Besides, the biological parameters were recorded. The study concluded that diet fortified at $2.5 \%$ and $5 \%$ dandelion powder helped to improve blood lipid levels in rats compared with positive control groups (injected with oxytetracycline).
\end{abstract}

Key words: Total cholesterol - dandelion.

\section{Introduction}

Atherosclerotic disease causes over 19 million deaths annually worldwide, yet our understanding of the fundamental aspects of the genesis of the disease remains incomplete. Several studies have shown that an increased dietary intake of cholesterol results in hypercholesterolemia, which is known to eventually generate atherosclerosis and enhance the risk of coronary heart disease (CHD), fatty liver disease and cancer associated with hydroxyl radical formation. The etiology of atherosclerosis appears to be a multifactorial series of events, but the oxidation of lipoprotein is believed to be a primary event in the pathogenesis of atherosclerosis. Thus, recent interest has been focused on strategies to enhance the removal of reactive oxygen species (ROS) by using antioxidants to enhance endogenous antioxidant responses (Choi et al 2010).

The genus Taraxacum Wiggers, family Asteraceae, subfamily Cichorioideae, tribe Lactuceae, commonly known as Dandelion, includes approximately 30-57 varieties with many microspecies, divided into nine sections (Vašut \& Majeský 2015). Dandelion (Taraxacum officinalis), a traditional herbal medicine is used for treatment of jaundice and disorders of the liver, gallbladder and other various hepatic ailments 


\section{Abdelrehman M. Attia et al}

(You et al., 2010 and Ahmed et al., 2013). Conventionally, root and herb from Taraxacum officinale have been reported to be used for the treatment of various ailments, including liver and gallbladder disorders (Gulfraz et al., 2014 and Devaraj 2016).

This study aimed to find the protective effect of Dandelion on non-alcoholic fatty liver in albino male rats.

\section{Materials and Methods}

\section{Materials:}

Egyptian cultivar of Dandelion was purchased from Field Crops Research Institute, Ministry of Agriculture Giza, Egypt. Soybean oil and starch were purchased from the local market. Casein, cellulose, vitamins \& minerals, dextrin, L-cysteine, choline chloride, and Cesplatin were obtained from the Cairo Company for Chemical Trading, Cairo, Egypt.

Twenty-eight male albino rats (Sprague Dawley strain) were obtained from the laboratory animal colony. Helwan, Cairo - Egypt. Weighting approximately between (150-180g). Kits used to determine cholesterol, triglycerides, LDL-C produced by Egyptian American Company for laboratory service and supplied by Alkan Company.

\section{Methods:}

Egyptian cultivar of dandelion was purchased from Field Crops Research Institute, Ministry of Agriculture Giza, Egypt.

\section{Preparation for dried dandelion leaves:}

The fresh dandelion leaves were washed with tap water then dried by cotton cloth to remove the excess water. The clean leaves were dried at $40{ }^{\circ} \mathrm{C}$ by Solar Energy and vacuum packaged until use. The leaves were ground into powder with a mill.

\section{Experimental design:}

Twenty-eight male Albino rats weighting $(120 \pm 15 \mathrm{~g})$ were put on basal diet for one week for adaptation prior to commencement of the experiment and housed in well aerated cages under hygienic condition. Water was introduced ad-libitum. After this week, rats were divided into 4 main groups (seven rats of each) fed on diets for eight weeks as follows: Group 1: Negative control group continued basal diet during the whole experiment.

Group 2: Positive control group was fed on basal diet for 28 days, then injected with Oxytetracycline for three consecutive days $(120 \mathrm{mg} / \mathrm{kg}$ body weight) and continued on the basal diet till the end of the experiment.

Group 3: continued as group 2 and after being injected rats were given Dandelion powder $2.5 \%$ on the basal diet.

Group 4: as the same of group 3 except that rats were given $5 \%$ Dandelion powder.

\section{Blood Sampling:}

At the end of the experiment period, the rats were fasted overnight then anaesthetized and sacrificed and blood samples were collected from the aorta. Blood was left to coagulate then centrifuged at $3000 \mathrm{rpm}$ for 15 minutes to obtain serum for each individual sample and then stored at $-20^{\circ} \mathrm{C}$ for laboratory analyses. (chapman et al., 1950) 


\section{Egypt. J. of Nutrition and Health Vol. 14 No. 1 January (2019)}

Biochemical analysis of serum:

Serum samples were used for the determination of total cholesterol (Allain et al., 1974), triglycerides (Fossati \& Prencipe 1982), HDL-C (Lopes et al 1977), LDL-C and VLDL-C were calculated by using the method of Friedewald et al., (1972).

\section{Statistical analysis:}

Results are expressed as mean \pm SD. Data were statistically analyzed for variance using oneway analysis of variance "ANOVA" according to Armitage \& Berry, (1987). Computer software system SPSS (version 15) was used for these calculations.

\section{Results and Discussion}

\section{Effects of dandelion on liver enzymes of rats ( table 1)}

Results revealed that, control positive group with oxytetracycline injection (120 mg/kg body wt.) showed a significantly higher $(\mathrm{P}<0.05)$ value of AST \& ALT compared with those of negative control group. This is attributed to the destructive effect of the drug on liver cells. However on feeding basal diet containing dandelion powder at $2.5 \%$ \& $5 \%$ for six weeks caused a significant reduction in the mean values of serum Aspartateamine transaminase (AST) and Alanineamine transaminase ( $A L T$ ) compared to the positive control group.

Our results are in agreement with (Helal, et al., 2012) treated rats with oxytetracycline for three consecutive days caused fatty liver, necrosis and inflammation. These histological changes were associated with the high significant increase in activities of serum ALT, AST. They attributed, the significant increase may be due to rise in free radicals decrease in the antioxidant enzyme levels. The significant decrease in serum transaminases AST, ALT activities in dandelion treated group elucidates the hepatoprotective effect of dandelion (Helal et al., 2012). The antioxidant, anti-inflammatory and free radical scavenging property of dandelion was ameliorated the effect of oxytetracycline on serum LDH activity through scavenge the free radicals, minimize lipid peroxidation, thereby preventing membrane damage and leakage of enzymes (Helal et al., 2012). It was suggested that, dandelion may offer protection to the myocardium by preventing the lipid peroxidation of membrane bound polyunsaturated fatty acids, thus ensuring myocardial membrane function. 


\section{Abdelrehman M. Attia et al}

Table ( 1 ):

Effect of feeding intoxicated rats with dandelion on serum liver enzymes

\begin{tabular}{|c|c|c|c|}
\hline $\begin{array}{ll}\text { Groups } & \text { Paramaters } \\
\end{array}$ & AST(u/l) & $\operatorname{ALT}(\mathrm{u} / \mathrm{l})$ & $\operatorname{ALK}(\mathrm{u} / \mathrm{l})$ \\
\hline Control (- ve) & $44.60 \mathrm{a} \pm 0.55$ & $33.00 \mathrm{a} \pm 2.83$ & $831.20 \mathrm{a} \pm 5.55$ \\
\hline Control (+ ve) Oxytetracycline injection (120 mg/kg) & $113.60 \mathrm{~d} \pm 7.56$ & $66.40 \mathrm{e} \pm 1.82$ & $850.80 d \pm 3.84$ \\
\hline $\begin{array}{l}\text { Control (+ ve) \& fed with basel diet }+2.5 \% \\
\text { Dandelion powder. }\end{array}$ & $51.80 \mathrm{bc} \pm 4.92$ & $38.80 \mathrm{~b} \pm 2.86$ & $847.40 \mathrm{~cd} \pm 2.07$ \\
\hline $\begin{array}{l}\text { Control }(+ \text { ve) } \& \text { fed with basel diet }+5 \% \\
\text { Dandelion powder. }\end{array}$ & $47.20 \mathrm{ab} \pm 2.49$ & $36.80 a b \pm 1.30$ & $842.60 b c \pm 6.19$ \\
\hline
\end{tabular}

Aspartateaminetransaminase ( AST ), Alanineaminetransaminase ( ALT ) and alkalaine phosaphate ( ALK )

Values at the same column with different letters are significantly different at $(p<0.05)$

\section{Effect of feeding dandelion powder on serum lipid profile of rats Triglyceride and total cholesterol ( table 2 )}

Results in table 2 indicated significant rise of serum Triglyceride (TG) and Total Cholesterol (TC) of the control positive group compared with the negative control group. However, on feeding rats the basal diets containing $2.5 \%$ and $5 \%$ levels of dandelion induced significant decrease $(p<0.05)$ in triglyceride and total cholesterol. Previous studies by (Choi et al 2010), showed that the diet with dandelion leaf also lowered both levels of triglyceride and LDL cholesterol significantly. Triglyceride level was significantly lower in the dandelion root group than in the control group.

Table ( 2 ):

Effect of dandelion powder on triglyceride and total cholesterol

\begin{tabular}{l|c|c}
\hline \multicolumn{1}{c|}{ Groups } & Triglyceride mg/dl & Cholesterol mg/dl \\
\hline Control (- ve) & $106.40^{\mathrm{a}} \pm 6.11$ & $141.60^{\mathrm{a}} \pm 8.62$ \\
\hline $\begin{array}{l}\text { Control (+ve) Oxytetracycline injection } \\
(120 \mathrm{mg} / \mathrm{kg})\end{array}$ & $190.00^{\mathrm{e}} \pm 5.09$ & $252.00^{\mathrm{c}} \pm 6.44$ \\
\hline $\begin{array}{l}\text { Control }(+\mathrm{ve}) \text { \& fed with basel diet }+2.5 \% \\
\text { Dandelion powder. }\end{array}$ & $144.60^{\mathrm{d}} \pm 6.34$ & $153.80^{\mathrm{b}} \pm 5.40$ \\
\hline $\begin{array}{l}\text { Control }(+\mathrm{ve}) \text { \& fed with basel diet }+5 \% \\
\text { Dandelion powder. }\end{array}$ & $133.20^{\mathrm{c}} \pm 5.63$ & $149.20^{\mathrm{b}} \pm 4.82$ \\
\hline
\end{tabular}

Values at the same column with different letters are significantly different at $(p<0.05)$

Effect of feeding dandelion powder on High density lipoprotein, low density lipoprotein and very low density lipoprotein ( Table 3 )

Results indicated that the positive control group were significantly higher in serum levels of low density lipoprotein and very low density lipoprotein and decrease in high density lipoprotein when compared with the negative control group. Rats which fed on diet fortified with dandelion powder at $2.5 \%$ and $5 \%$ had lower mean values of Low density lipoprotein cholesterol ( LDL-C ) and Very low density lipoprotein cholesterol ( VLDL-C ) compared with the positive control group. On the other hand, all treated groups with fortified diet at different levels of dandelion had higher mean values of High density lipoprotein cholesterol ( HDL-C ) compared with the positive control group. This was matching with previous studies by (Bhandari et al., 2005) and (Choi et al 2010). Dandelion leaf supplementation resulted in significant increase in the levels of HDL cholesterol. The diet with dandelion leaf also lowered both levels of triglyceride and LDL cholesterol significantly. 
Egypt. J. of Nutrition and Health Vol. 14 No. 1 January (2019)

Table ( 3 ):

Effect of feeding experimental rats on Dandelion powder on High density lipoprotein cholesterol

( HDL-C),

Low density lipoprotein cholesterol ( LDL-C ) and Very density lipoprotein cholesterol ( VLDL-C )

\begin{tabular}{l|c|c|c}
\hline \multicolumn{1}{c|}{ Paramaters } & HDL-C mg/dl & LDL-C mg/dl & VLDL-C mg/dl \\
\hline $\begin{array}{l}\text { Groups } \\
\text { Control (- ve) }\end{array}$ & $45.00^{\mathrm{e}} \pm 2.23$ & $75.32^{\mathrm{a}} \pm 10.12$ & $21.28^{\mathrm{a}} \pm 1.22$ \\
\hline $\begin{array}{l}\text { Control (+ve) Oxytetracycline injection (120 } \\
\mathrm{mg} / \mathrm{kg})\end{array}$ & $35.60^{\mathrm{a}} \pm 1.51$ & $178.40^{\mathrm{d}} \pm 5.91$ & $38.00^{\mathrm{e}} \pm 1.02$ \\
\hline $\begin{array}{l}\text { Control (+ ve) \& fed with basel diet }+2.5 \% \\
\text { Dandelion powder. }\end{array}$ & $40.80^{\mathrm{bcd}} \pm 1.30$ & $84.08^{\mathrm{bc}} \pm 4.61$ & $28.92^{\mathrm{d}} \pm 1.27$ \\
$\begin{array}{l}\text { Control (+ ve) \& fed with basel diet }+5 \% \\
\begin{array}{l}\text { Dandelion powder. } \\
\hline\end{array}\end{array}$ & $43.20^{\mathrm{de}} \pm 2.39$ & $79.36^{\mathrm{ab}} \pm 4.44$ & $26.64^{\mathrm{c}} \pm 1.13$ \\
\hline
\end{tabular}

High density lipoprotein cholesterol ( HDL-C ), Low density lipoprotein cholesterol ( LDL-C ) and Very density lipoprotein cholesterol ( VLDL-C)

Values at the same column with different letters are significantly different at $(p<0.05)$

The study concluded that dandelion powder helped to improve blood lipid levels in albino rats intoxicated with oxytetracycline.

\section{References}

Ahmed,D.; Gulfraz,M.; Ahmad,M.; Tahir,R. \& Anwar,P. (2013).

Cytoprotective potential of methanolic leaves extract of Taraxacum officinale on CCl4 induced Rats. Pensee J.; 75:220-227.

Allain,C., L. Poon, C. Chan, and W. Richmond, 1974.

Enzymatic determination of total serum cholesterol.Clinical Chemistry, 20: 470-475.

Armitage,P. and Berry,G.(1987).

Statistical methods in medical research. Distributors, USA, Year Book Medical Publishers. ISBN 632- 05257.

Bhandari,U.; Kanojia,R. and Pillai,K.(2005).

Effect of ethanolic extract of Zingiber officinale on dyslipidaemia in diabetic rats, J. Ethnopharmacol. (97 ) 227-230.

Choi U., Lee O. Yim J. Cho C. Rhee Y. Lim S. Kim Y. (2010).

Hypolipidemic and Antioxidant Effects of Dandelion (Taraxacum officinale) Root and Leaf on Cholesterol-Fed Rabbits. International Journal of Molecular Sciences. 11, 67-78.

Devaraj,E. (2016).

Hepatoprotective properties of Dandelion. J. of Applied Pharmaceutical Science Vol. 6 (04), pp. 202-205. 


\section{Abdelrehman M. Attia et al}

Fossati, P. and L. Prencipe, (1982).

Serum Triglycerides Determined Colorimetrically with an Enzyme that Produces Hydrogen

Peroxide. Clinical Chemistry, 28, 2077-2080.

Friedewald, W., R. Levy and D. Fredrickson, (1972).

Estimation of the concentration of low-density lipoprotein cholesterol without the use of the preparative ultracentrifuge. Clini. Chemi. 18: 499-502.

Helal,E.; Abd El-Wahab,S.; Sharaf,A. and Zedan,G. (2012).

Effect of Zingiber officinale on fatty liver induced by oxytetracycline in albino rats. The Egyptian Journal of Hospital Medicine. 46( 26 ): 42 -26.

Gulfraz,M.; Ahamd,D.; Ahmad,M.; Qureshi,R.; Mahmood,R.; Jabeen,T. \& Abbasi,N. (2014).

Effect of leaf extracts of Taraxacum officinale on $\mathrm{CCl} 4$ induced hepatotoxicity in rats, in vivo study. Pak J Pharm Sci; 27:825-829.

Lopes, M., S. Stone, S. Ellis and J. Collwell, (1977).

Cholesterol determined in high denisty lipoprotein separated by three different methods. Clin. Chem.; 23 (5): 882.

Vašut,R. \& Majeský,L'. (2015).

Taraxacum pudicum, a new apomictic microspecies of T. section Erythrosperma (Asteraceae) from Central Europe. Phytotaxa; 227:243- 252.

You,Y.; Yoo,S.; Yoon,H.; Park,J.; Lee,Y.; Kim,S.; Oh,K.; Lee,J.; Cho,H. \& Jun,W. (2010).

In vitro and in vivo hepatoprotective effects of the aqueous extract from Taraxacum officinale (dandelion) root against alcohol-induced oxidative stress. Food Chem Toxicol 2010; 48:1632-1637. 
Egypt. J. of Nutrition and Health Vol. 14 No. 1 January (2019)

التأثير الوقائى للسريس على الدهنيات فى الجرذان المصابه بالاوكسى تيترا سيكلين

عبد الرحمن محمد عطيه ، أمنيه جلال رفعت ، منى سامى حلبى ، الاء أسامه أبو ريه ساره عاطف على محمود

قسم التغذيه و علوم الاطعمده ـ كليه الاقتصاد المنزلىـ جامعه حلوان

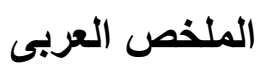

ينتشر نبات السريس فى كثير من البلدان لفائند التخذوية والعلاجية وتهدف هذه الدراسة الى معرفه تأثير السريس

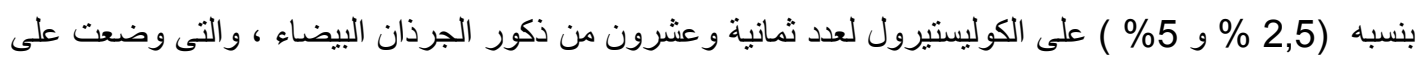

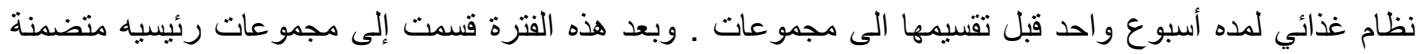

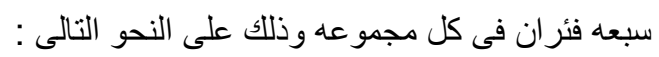

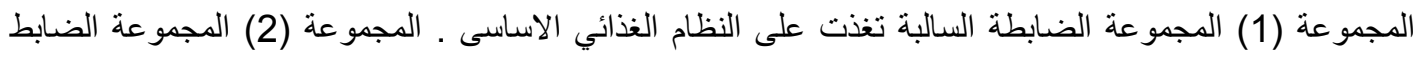

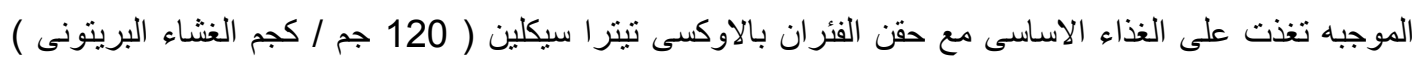

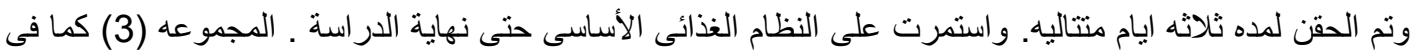

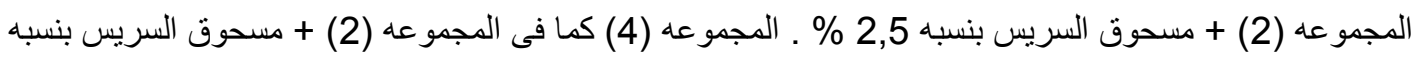
. \% 5 في نهايه فتره التجربه ، تم جمع عينات الدم من الثريان الاورطى لتنقير نسب الدهون فى الدم ، وتقدير وظائف الكبد

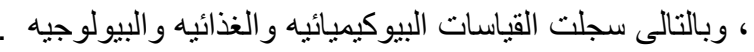

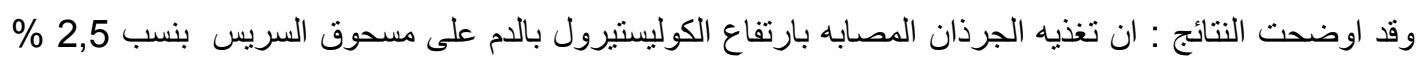

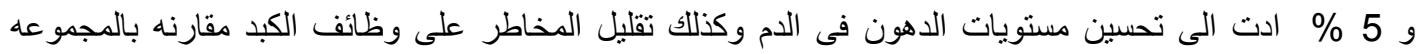
الضابطه الموجبه ( التى تم حقنها بالاوكسى تيترا سيكلين ) ) .

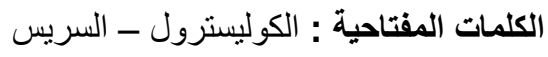

